\title{
鶏の比較解剖学的並びに局所解剖学的研究
}

\section{XVII. 舌下神経，副神経および舌咽神経の末梢走向}

\author{
渡辺徹 \\ 名古屋大学震学部家凅解剖学教室 \\ 主任： 保田翰男教授 \\ （昭和 39 年 1 月 10 日受付）
}

鳥類に扣ける臽下神経，副神経执よび舌咽神経の 来梢走向执よび分有については，すでに $\operatorname{CoRDS}^{3)}$ お よび STRESEMANN ${ }^{2 \cdot 1)}$ によって記述された，彩にお けるそれらについては，KAUPP(14) が詳細に記載して いる.しかしこれらの文献に拈いて，筋系および種 々の器宦に分布する神経の走向，分枝执よびそれら の学名についての見解は, 必ずしも一致していない. それ故に，ここでは文献を参照して，特に学名と和 名とを整理, 検傠し, 適切と思われる学名を表示す るよらに試みた。また図の作成にあたっては，でき る限り，実物を忠実に写し取るように努力した。な お筋の学名については藤岡 ${ }^{5)}$ の観祭結果および学名 を参照した。

\section{材料および方法}

材料は，生後 6 力月以上，当教空で飼養中のロー ドアイランドレッド種 10 例，白色レグホーン種 5 例を用いた。 また付図は，ロードアイランドレッド 種 5 例の肉眼的解副所見を主とし，白色レグホン種 の所見を参考にして描いた。なお訏細な点の観察 は，双眼解剖顕微鏡によった。 または図の作成に際 して,筋の形態および起始・停止については，藤岡 ${ }^{5}$ の付図を参照し，また彼の所兌の教示を受けた。

\section{観察扣よび考察}

\section{I 、舌下神経}

舌下神経は，延髄腹外側潅より，ほぼ 2 本の神経 根として現わ扎る，それらを形成している小根の数 については，個体差があるが，吻側の神経根は 8〜 10 本，尾側のものは 14 15 本の小根から成り，前 者のほうが後者よりもかなり細い、また尾側の神 経根のすぐ尾側からは，第一頸神経根が現われる
(Fig. 2)．な拈著者22)は，後頭骨と第一頸椎との䦗 から出る神経を，第一頙神経とした。

この舌下神経根の数について，FÜRBRINGER ${ }^{67}$ と PORTMANN $^{199}$ は，3本㜔められることもあるが，最 も吻側の神経根は，退化しやすいと述べている。 さ らに PORTMANN ${ }^{199}$ は, 舌下神経根は発生初期に 5 本 存在するが，成長とともに減少して，2３本にな ると記速している。 また CORDS $^{3)}$ と $\mathrm{KAUPP}^{14)}$ は， 吻側と尾側の 2 本の神経根があると記載している. HAMILTON $^{10)}$ は, ChIARUGI を引用して, 鷄では発生 初期に小さい神経節が形成されているが，卯卵 4 日 目には退化して，神経節をもたない神経になると記 載した. PORTMANN ${ }^{19)}$ も同じ見解を報告している. この吻・尾に相並んだ 2 本の神経根を，CoRDs ${ }^{3)} は$ vordere Wurzel および hintere Wurzel と名付けて 説明している。そ机故に，著者も CORDS ${ }^{3)}$ に從い， 吻侧根 Radix cranialis と尾側根 Radix caudalis と 名付けることにしたなな扮 $\mathrm{KAUPP}^{14)}$ は，著者の観 察とは逆に，吻側根のほうが尾側根よりも大きいと 記載している。これは Kaupp ${ }^{(4)}$ の観察の譟りであ るのか，あるいは用いた材料の巠翼による不一致で あるのかは決めがたい。

この 2 本の神経根は，斜め腹尾方に走り，それぞ れ固有の孔を通って，頭蓋腔を去る.この孔につい ては，単に後頭骨にある 2 つ小さい孔として説明 している文献もあるが，BONSDORFF' は Foramen condyloideum という学名を用い，KESTEVEN ${ }^{15)}$ は hypoglossal foramen と名付け，また加藤(13) は舌下 神経孔という和名を採用している，最近，藤岡ら4) は Foramen nervi hypoglossi と名付けた。著者は， これらの神経孔が，後頭顆の両側に，背腹 2 対の孔 として存在し，背側のほうが腹側よりも大きく，背

日獣誌 26,249～258（1964） 
例の孔を尼侧根が，腹側の孔を吻侧根方通過してい る所見をえた (Fig. 3). したがって2つの孔を，そ れぞれ Foramen nervi hypoglossi dorsale et ventrale （背・腹舌下神経孔）と名付けることにした，多くの 場合，この神経孔は 2 つに分かれているが，ロード アイランドレッド種の1例では, 1つしかなかった. このような例では，神経根の走向もかなり異なって いて，尾側根は大後頭孔を通り，第一頸神経ととも に，走って打り，吻側根のみが 1 つの标下神経孔を 通っている.

神経孔を出た後で,吻側根と尾側根とは, KAUPP ${ }^{14)}$ 33 anterior branch と posterior branch として説明 したように，R. anterior (前枝)と R. posterior (後 枝）と名付けるべきであるう，後枝は M. trachelomastoideus の停止部の内侧を腹侧に走り，M. rectus capitis ventralis の背侧陑に接して，外側へと走る. その際後枝は，M. rectus capitis ventralis に小枝を 分有させている. 一方,前枝は神経孔を通過した後, M. trachelomastoideus の停止部を斜めに買通し，次 いで交感神経系の上頸神経節からの吻合枝を受け る。著者はこの物合杪在，R. communicans cum ganglio cervicali superiori (上頚神経節との交通校) として整理した (Fig. 6). KAUPP ${ }^{14)}$ は，舌下神経 が交感神経と交美するところに，带型的な项交感神 経節が形成されると述へている，しかし，著者の肉 腿的観察では，そのような神経節は認められなか。 た．次いで，前枝と後枝とは吻合する。これに続い て，第一頸神経からの昒合枝が加わる。この物合枝 を, CoRDs ${ }^{3)}$ は Ram. comm. c. n. cervical. primo と名付けた，著者の镜祭絬果も同じである故ここで はこの学名をそのまま踏竞した。このようにして舌 下神経幹が成立する (Fig. 6)。

舌下神経は，以上述へたように，他の神経枝を受 けているので, 神経叢を形成する. STRESEMANN ${ }^{2 n)}$ およびKAUPP ${ }^{14)}$ は，それをN. hypoglosso-cervicalis として説明し，また VAN DER HORST ${ }^{122} は$, Plexus hypoglosso-cervicalis と名付け，時には第二頸神経が 介入することもあると述べた，事実，著者も，臽下 神経孔を1つしかもたないロードアイランドレッド 程の 1 例で，第二頸神経が舌下神経に吻合すること を観祭している，他方，CORDS ${ }^{32}$ は，舌下神経に吻 合する枝全部に学名を与克，HÄCKER ${ }^{8)}$ にしたがい Plexus cervicalis と呼んでいる. しかし著者の観察 結果は，より多くの点でVAN DER HORST ${ }^{12)}$ の所見
と一致しているので, ここでは Plexus hypoglossocervicalis（舌下頸神経譜）という学名を用いること にした。

舌下神経翰は， M. rectus capitis ventralis と M. rectus capitis lateralis の問から, 頸筋群の外側に出 $\tau$ ，迷走神経と舌咽神経の咽頭枝と交差し，兲垻上部 の腹側へと迂回して行く．その際この 2 つの頭神経 に，それぞれ細い吻合枝を分岐している (Fig. 6). CORDS ${ }^{3)}$ に従えば，この吻合枝は Rr. comm. c. n. glossopharyngeo et vago である. 著者の観察もこれ に一致しているので，この学名を踏意した．吕下神 経幹は，迷走拈よび舌咽神経との交差点の間で，䫭 静脈に伴われて下行する1本の細い枝を分岐する. この枝は，项部の中部まで走り下った後，项静脈か ら離れて，M. sternolaryngeus の中块部に分有して 終る (Figs. 6，9).この枝については，すでに HÄCKER $^{8)}$ 抢よび STRESEMANN ${ }^{20)}$ が R. cervicalis descendens inferior として記载しているので，穜者 もこれに従い，和名は下下行项枝として整理した． しかしこの学名は，その和名とともに，将来検討さ れねばならない。

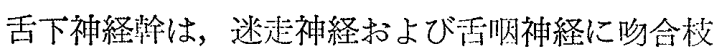
を分肢する前後から，蛇行走向を示しながら，钲下 部腹側へと迂回するが，その途上で 2 枝に分かれる. この 2 枝に分岐するまでの舌下神経を，HÄCKER ${ }^{8)}$ は R. cervicalis として説明している. 上述のように, 2 枝に分岐した後に，その 1 枝は，頸上部の腹侧前 面へと上行していく校で，鶂の頸部を例皮した際， Platysma の内側に潜入していく枝である。この枝 を, BONSDORFF ${ }^{1)}$, CORDS $^{3)}$ およびSTRESEMANN ${ }^{20)}$ は R. lingualis と名付け, GADOw und SELENKA laryngolingualis と名仙け，また KAUPP ${ }^{(4)}$ は recurrent laryngolingualis として記载している，著者の観 察によれば，この枝からの分枝は，舌骨に付着する 筋のみならず，喉頭上部拉よび気管の筋である M. hyomandibularis と M. laryngohyoideus にも分布し ている (Fig. 8). そこで, GADOW und SELENKA お よび KAUPP ${ }^{14)}$ の見解に御い，Rr. laryngolinguales (崛頭舌筋枝) と名付けることにした。

この枝は，本幹加ら分岐されると，すぐに M. hyomandibularis の内側に潜入し，その筋に対する 被を分かつ (Fig. 8). 次いで喉頭腹面を，下唨腹側 に向かって走るが，間もなく M. laryngohyoideusに 分布する校を分かつ，残りの部分は，吻側に走って， 
M. interceratoideus への枝を分かつ.この筋の尾側 部には，舌下神経が分有するが，吻㒋部には，三灭 神経の下顎神経が分称している，それ故，この筋は 二西支配を受けていることになる (Figs. 5，8). 残

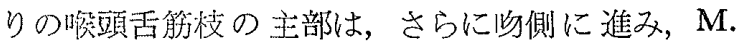
ceratoglossus に分存し (Figs. 5，8), 次いて $\mathrm{M}$. hyoglossus medialis と, M. hyoglossus lateralis の腹 证に分布している (Figs. 5，8).

な打 KAUPP ${ }^{14)}$ によれば, recurrent laryngolingualis は，第一括よび第二頸神経から，知覚性の要素を受 け，ことにアヒルのように檿舌をもつものでは， より多くの知覚線維党受けている。 また STRESEMANN $^{20)}$ \&，R. lingualis は湿合性で，知覚線維は答 髄神経に届来し，終末は舌の味蕾にまで達している と記載した。しかし現在，これらの見解を検討する ための充分な根拠をもっていないので，この点につ いては,将来さらに検討を加えていくつもりである.

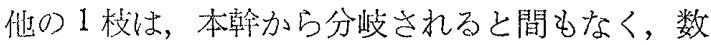
本の玟に分加る (Figs. 8，9)。 これらの枝を， BONSDORFF $^{1)}$, CORDS $^{3)}$ およびSTRESEMANN ${ }^{20)}$ は,Rr. laryngei superiores と名付忖，KAUPP ${ }^{14)}$ は recurrent laryngeusとして記载している，著者の維祭結果は， Cords $^{3)}$ の所見に一致して抢り，ここでは Rr. laryngei superiores（上喉頭枝）という学名を用いる ことにした。これらの枝は，分枝された後も蛇行走 何走示し，迷走神経の㗱頭枝执よび咽頭枝と密接な 関係を示しつつ，さらに多くの細玟に分かれて，M. sternolaryngeus 㐨よび M. trachealis lateralis の内側

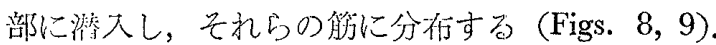
これら組枝のうち，1 枝は M. trachealis lateralisの 中心部を縦断するように走下する。この枝は，この 筋に対する動脈枝に伴われて，鸹管の高さにまで羍 している.そしてその終末枝は，M. sternotrachealis の停此部に分侈して終わる。この枝は，すでに CoRDS $^{3)}$ が R. cervicalis descendens superior として 記械したものに相当する。なお $\mathrm{KAUPP}^{14)}$ および STRESEMANN $^{20)}$ も，この校の存在を認めている。これ

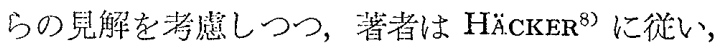
R. syringeus（㺞管枝）として整理した（Fig. 9).

II. 们神経

耐神経の起始根は，迷走神経根の尾側に連続し，

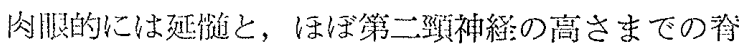

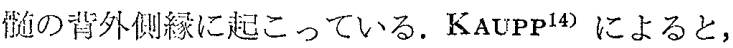

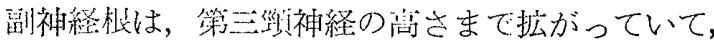

第一抢よび第二頸神経根から，それぞれ小根を受け ている、また CoRDS ${ }^{3)}$ は，第二頸神経の高さまでに 起こるとしている，著者の観祭結果によれば，副神 経根は，CORDS ${ }^{3)}$ の所見と同様に，第二钼神経の高 さまでに起こっている.しかし KAUPP ${ }^{14)}$ が記載し ているように，第三钼神経の高さに副神経根の起始 があるかどうかについては，さらに多数例を詳縕に 観察しな宁れば何斗いえない。

これらの小根は，尾側から吻側に進むにつれて，

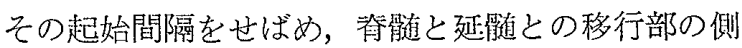
面に㧍いて，組い幹となり，腹側に斜走して，大後

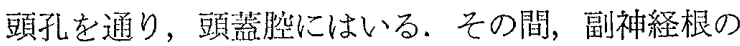
組い幹は，総計 10〜15 本の小根を集めて，迷走神 経幹の最尾側に加わる (Fig. 1).

この副神経根は，哺乳類では，多くの人々により， 延髄枝と脊髄枝とに区別されている。しかし鶏では， そのような区分は．余り明確ではない，また内枝と 外枝との区分についての見解も区々である。これら の点は，HOLL ${ }^{11)}$ 以来,論議の中心であった.HOLL ${ }^{11)}$ は，副神経のうち，内枝だけが副神経であって，外 权は瓷推神経に数元られると述べた。これとは逆に， FÜRBRINGER ${ }^{6)}$ は，舌咽神経と迷走神経とを合わせ $\tau$ ，Vago-accessorius とし，副神経を R. externus s. posterior としている. LuBosch ${ }^{17)}$ は, accessoriusvagi と spinalis との区別は，比较解剖学上全く根拠 がないと主張している. CORDS $^{3)}$ を，副神経の内枝 が，迷走神経の中に移行することを疑問視して扣り， 外枝は，迷走神経と結合しているが，独立したもの であって，てれ故，外枝こそ副神経であると述べた。

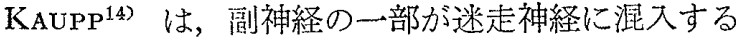
が，他の一部は細い枝で，筋枝となると記載してい る. PORTMANN ${ }^{19}$ は，副神経は，迷走神経の1つ0 根でもないし，また哺乳類で認められるように，独 立したものでもないと述べた，鶏におけける観祭結果 および神経切除実験の結果から，著者は，副神経の

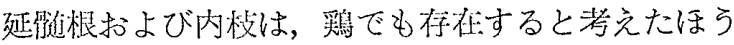
が，羂当であるように思う。しかしそれらは，迷起 神経と走向を全くともにしている（Fig，1）。な打鷄 には，哺乳類のように，上啖頭神経が存在しない。 そのため現在のところ，副神経の延佣过根の線維が， どこに分布しているかを論ずる根拠を持ち合わせて いない.

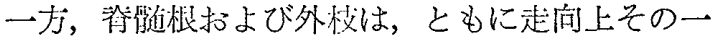
部は迷走神経鉝に包念されるが，CORDS ${ }^{3)}$ も述べた 
徹

ように，外枝こそ副神経そのものであるとしたい。 副神経は，迷走神経幹に包含されて，迷走副神経 孔を通り．頭蓋腔を去る。この神経孔の出口におい て，迷走神経は迷走神経根神経節を形成するが．そ の背尾側㧍よび迷走・舌㸶神経交通枝から，副神 経は分岐される (Fig， 6)。 そして M. occipitomandibularis と M. ceratomandibularis $\sigma$ )間を外側に でて, 2 枝に分岐し, CHAMBERLAIN ${ }^{2)}$ の M. cutaneus colli lateralis の起始部に分布する (Fig. 4).この筋 を, CoRDS $^{33}$ 抢よびSTRESEMANN ${ }^{20)}$ は Mm. cuculares とし，KAUPP ${ }^{14)} は$ subcutaneus colli と:している.

一方保田ら ${ }^{23}$ ) 4 ，鳥類において子，副神経に支配 される筋を，M. trapezius とするのが，妥当である と考光，鷄に括ける M. rhomboideus superficialis を，M. trapezius と名付けるという，過去の文献の 嵒りを，整理するために，鳥類では，僻帽筋から分 離した皮筋があるとする西年のの見解に往い，副神経 支配の M. cutaneus colli lateralis の吻側部に，M. trapezius の存在を区別した，この見解は，副神経の 外枝が，この筋を支配しているという著者の観察結 果から嵲かれたものである。

\section{III. 舌咽神経}

舌咽神経は，延艏の外侧緣に打いて，迷走神経根 の吻側に連続し，約 15 本の神経根をもって起こり， 迷走神経掞よび副神経の根線維とともに，愊広い1 本の翰にゆるく集合し，神経上膜に包: れている (Fig. 1).この离さにおいて，舌明神䋩幹はわずか ながら膨隆するここの部位を組織学的に観祭すると， 若一の神経節縕胞を認めることができる。 YNTEMA apd HaMmoND ${ }^{24)}$ は，卵卵 8 日目の鷄の胎児で，第 9 脳神経の根部を Superior ganglion と名付けてい る. HALLER ${ }^{92}$ は，堅類の舌咽神経は，爬虫類のそれ と同様に，2つの神経節をもち，その 1 つは近位に ある Wurzelganglion，すなわち Ganglion superius で，他は遠位にある Ganglion petrosum であると記 述している。

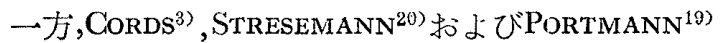
は，この近位の神経節に Ganglion jugnlare という 学名を与えている。他方，HAMILTON ${ }^{10)}$ は，それを superior ganglion と名付けている. 哺乳類の迷走神 経の近位にある神経節は，Ganglion jugulare と名付 けられているので，彩の吉咽神経のそれに同一名を 使用することは，非符に混乱を起こしやすい，すで に著者 ${ }^{21}$ は，迷起神経の近位の神経節に一 Ganglion radicis vagi（迷走神経根神経節）という学名を使用 しているので,ここでは，これにならって Ganglion radicis glossopharyngei（舌咽神経根神経節）という 学名を用いることにした (Fig. 6).

舌咽神経，迷走神経打よび副神経の小根群は，ゆ るく集合した後に．舌咽神経幹と迷走・副神経幹と になり，それぞれの神経孔を通って，頭培膛を去る。 この舌明神経の通過する神経孔についての記載は, 研究者によって必ずしも一致していない，CORDs ${ }^{3)}$ 抢よびSTRESEMANN ${ }^{20)}$ は, Foramen jugulare を通っ て，舌咽神経が頭蓋腔を去ると述べているが，これ は鳥類一般についての記述であり，鶏には当てはま らないように思われる. GADOW und SELENKA ${ }^{72}$ は， Foramen lacerum posterius という哺乳類の学名と同 じものを使用している. KAUPP ${ }^{14)}$ の記載によると， 舌胭神経は Foramen jugulare et caroticumを通る。 この点についての KESTEVEN ${ }^{15}$ の記載は，妥当と思 われる，彼によると．後頭骨の頭蓋腔面には，Fossa for nerves ganglia of IX, X and XI と名付けられ る䆟がありこの營から， vagoaccessory foramen と glossopharyngeal foramen とが外僛に延び，そのう ち後者は, Fossa parabasalis の内縁にその外側の出 口をもっている.

この 2 つの神経孔は, 多くの場合, 離れて存在し ている.しかし時として両者は，頭蓋の内側では 1 個の神経孔で始まり，頭蓋の外側では，わずかに唯 れており，雨者の間に薄い骨板を拆む程度の場合も ある。これは，すでに KAUPP ${ }^{14)}$ が，両神経の間に a thin portion of bone が存在することを涊めている のと, 同一の所見である. また最近，藤岡ら の頭蓋骨にある神経孔について考察し,KESTEVEN ${ }^{15)}$ と同様，舌咽神経が通過する神経孔を Foramen nervi glossopharyngei (舌咽神経孔) と名付けている (Fig. 3).

舌咽神経孔の出口にお゙いて, 舌顺神経幹は幾分膨 隆して，第 2 の神経節を形成する.この神経節の学 名は, 多くの研究者が一致して, Ganglion petrosum としている。これに從って，著者も Ganglion petrosum (錐体神経節) という学名を用いることに した (Fig. 6).

錐体神経節と迷走神経根神経節との間の腹側に

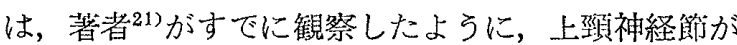
ある.この神経䬣は．錐体神経節㧍よび迷走神経根 神経節と，吻合枝で結ばれている (Fig.6)。これら 
3 つの神経節は, $M$. rectus capitis lateralis と $\mathbf{M}$. rectus capitis ventralis，抢よび $M$. trachelomastoideus の停正部に目をれた部位にある。この付近では，舌 咽神経幹は，迷走神経幹とともに，内頸動脈にそっ ている. 舌咽神経幹は, 錐体神経節を形成した後, その尾側部で 2 分し，1枝はただちに吻外側に走る.

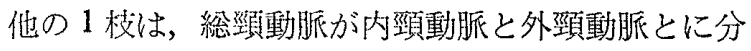
かれる部位よりも䢟位では,頸静脈の腹側にそって， 钼部を走下する。

次に舌咽神経幹から出される個々の神経枝につい て記述する。

1. R. sphenopalatinus（蝶形口盍枝）

この枝は，錐体神経節の頭側部から，腹頭側に问 かって分岐されて，上頸神経斯からの枝とともに， 内项動脈にからみつき，脳底部に潜入する。恐らく この枝に相当すると思われる神経枝に関して, HAL$\mathrm{LER}^{93}$ は，次のように記述している。

“錐体神経䬦から出た 1 枝は，上晫神経節からの 枝と吻合し，さらにまた N. palatinus VII と結合 し，内莖動脈にそって頭衤底に向かっている，また その一部は，眼简にもはいっている．そのような走 向状態加らみると，この枝は，爬出類の R. communicans internus に相当するものであろう。

また CoRDS $^{3)}$ は, BoNSDORFF ${ }^{1)}$ が記載したとおり， 舌胭神経からの 1 枝が, Ganglion cervicale supremum の高さで，その神経節からの分枝と吻合し，N. facialis の R. palatinus と結合する枝 R. sphenopalatinus を作ると報告している。 な招 GADOW und SELENKA ${ }^{7)} は$, この枝を N. sympathicus caroticocephalicus と名付けている. 以上の考察から, 著者 は, GoRDS ${ }^{3)}$ に徉って，R. sphenopalatinus (蝶形口 鲕枝）という学名を，この神経枝に与えることにし た (Fig. 6).

2. Rr. communicantes cum nervo faciali (顔面 神経との交通枝)

この玟は，錐体神経節の頭外側部より起こって， 外侧に走り，顔百神経の後枝と吻合する，なおその 一部は，上䣆神経節とも伆合している (Fig. 6).こ の交通枝を，CoRDs ${ }^{3)}$ は， Ram. corn. c. r. post. n. facialis と呼九でいる，彼文によれ奖，上頸神経節 の高さで，吉眭神経は，兴面神経の主枝である後枝

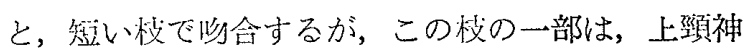
経節とも钐合している.STRESEMANN20) は,この枝の 存在を認好ているが，学名を与えていない，従った
著者は, CoRDS $^{3)}$ の所見に従い, Rr. communicantes cum nervo faciali (顔面神経との交通枝) として整 理した (Fig. 6).

3. R. lingualis (舌枝)

舌咽神経幹は，錐体神経節を形成した後，ただち に二分する (Fig. 6). その 1 枝は外側に走り，M. occipitomandibularis と M. ceratomandibularis の間 を，腹側に斜走して，下顎部の腹面に至り， $\mathrm{M}$. hyomandibularis $の$ 内側を走り，M. ceratoglossus $の$ 外側を,深部へと潜入して行く．この枝については，

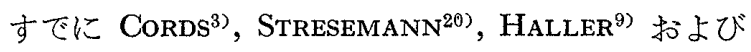
PORTMANN $^{19)}$ は，いずれも R. lingualis という一 致した学名を用い，KAUPP ${ }^{14)}$ \& recurrent lingualis として記述している.なお CORDS $^{3)}$ によると,この 枝は，倠や鴨の類では非常に大きく，舌咽神経の主 枝であるが，彩では，それらに比して，はるかに細 い. 舌枝からは, 次の分枝が出る.

（1） Rr. ad musculum ceratomandibularem (角 下顎筋に対する枝)

舌枝は，その走向上，舌骨弓大角の関節部で， M. ceratomandibularis への枝を分岐する.これらの 枝は, M. ceratomandibularis の腹側面に分布してい る (Fig. 8),この筋には，そのほかに顔面神経の枝 が分布しているが，この点については別に検討する. この枝を, CoRDS $^{3)}$ は, R. ad M. geniohyoideum と して記載し，STRESEMANN ${ }^{20)}$ および HALLER ${ }^{9)}$ む, かかる筋枝の存在を認めている。

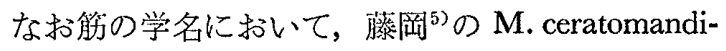
bularis は, ChamberlaiN ${ }^{2)} の$ M. hyomandibularis に，また加藤 ${ }^{13)}$ の M. stylomandibularis に相当す る.この筋の神経支配について, ChAMBERLAIN ${ }^{2)}$ お よび加藤 ${ }^{13)}$ は顔面神経によるものとし，舌咽神経の 関与についてはふれていない.しかし CoRDs ${ }^{3)}$ およ び STRESEMANN ${ }^{20)}$ も認めているように,この筋は， 舌咽神経に支配されて扣り，著者の観察では，顔面 神経も分倠していて，いわゆる三重支配を受けてい るものである.

その後, 舌枝は, M. hyomandibularis (藤岡 ${ }^{5)}$ ) の 内側を吻側に走り，Gll. submandibulares posteriores の腹側に達する.

(2) Rr. ad gll. submandibularem posteriorem et anteriorem（前・後顎下脉に対する枝）

舁枝は，後顎下腺の腹面に達すると，この豚に対 する細枝を分岐する (Fig. 8). なお，この腺の学 
名についての見解は, 研究都により区及である. CORDS $^{3)}$ は Glandulae sublingulae とし，またSTRESEMANN $^{20)}$ は Glandulae mandibulares とした。加藤 ${ }^{13)}$ は Gll. submandibulares posteriores (後顎下腺) と し，最近，鬿頭ら ${ }^{16)}$ も，加藤 ${ }^{13)}$ と同一の見解を発表

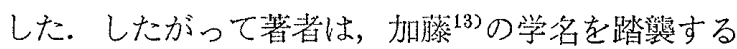
ことにした。そのはかに KAUPP ${ }^{14)}$ が，この腺に対 する神経秘を認めている。

後顎下腺への枝を出した後, 舌枝は，さらに吻侧 に走り，Gll. submandibulares anterioresにも細枝を 与えている。舌枝の終未枝は，さらに吻背側力，舌 の下面に潜大して終わる（Fig. 5)。この終末枝を， CoRds $^{3)}$ は, BonsDorfF ${ }^{1)}$ に従って, R. lingualis sens. strict. と名付け，舌背の角質活，中央部にある 味奮に分布すると記述した.KAUPP ${ }^{14)}$ 䄱よびSTRESE$\mathrm{MANN}^{20)}$ も，この枝の存在を認めている. しかし著 者は，この終末枝に，あえて学名を与㓍ないで，単 に舌枝の終末枝として記述するにとどめた。なお CORDS $^{37}$ は，舌枝にRr. pharngei があると報告して いるが，著者の観祭した限りでは，罵には，このよ うな神経枝は認められなかった。

4. R. pharyngeus (咽頭校)

上述の舌衼とともに，舌咽神経幹から分岐された

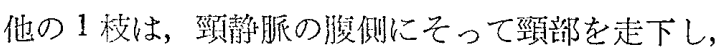

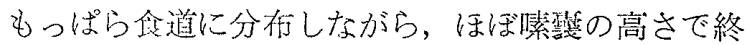
末枝となって終わる (Figs. 6，7，9)。

この神経枝を，研究者の多くは，R, pharyngeus としているが， BONSDORFF ${ }^{1)}$ は R. pharyngeus s. posteriorとし，また KAUPP ${ }^{14)}$ は recurrent pharyngeus としている.この学名については,余り買論はない。 次に，この神経枝加らの分校について迅べる。

(1) R. communicans cum nervo glcssopharyngeo (舌栶神経との吻合枝)

この沕合忮については，すでに著者泣が記述し た。舌朋神経に主体性を置いて考える上，この吻合 恔は，R. communicans cum nervo vago (迷走神経 との㕫合枝）とすべきであるが，阙一物に二つの学

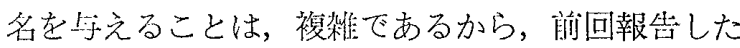
学名をそのまま引用した。

この枝は，送走神経根神経節の尾側部加分岐さ れて，活明神経の胭磌校に一見吻合するが，その包 合は染全でなく，単に斜めに癸きつくたけで，一部

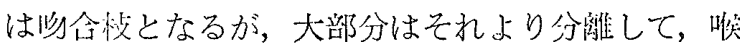
頭およず国䫒の㕫側部に起っている (Figs. 6, 7,9).
これらの終末神経枝を，著者 ${ }^{21}$ は，迷走神経の㸶 頭枝および喉頭枝として記述した。しかし CORDS ${ }^{3)}$ およびSTRESEMANN ${ }^{20)}$ の見解は異なっている，彼等 によれば，咽頭枝は，舌咀神経の第二の主枝であり， 舌枝から分岐した後，さらに二分する. その1枝が R. descendens s. oesophageus superior で，他の 1 枝 が R. anterior r. pharyngei であるとされている. そこで, CoRDs $^{3)}$ に従うならば, 迷走神経には, 咽頭 枝および聅頭枝は存在しないことになる。

それ故，著者は HALLER ${ }^{9)}$ の見解に賛成である. 彼は，鳥類では，迷走神経の強大な 1 枝が，舌哒神 経に加わり，その後，いわゆる舌咽神経の胭頭枝に 続いているが，その神経枝の本質的な部分は，迷走 神経の線維から成りたっているので，この神経枝の 中には，哺乳類で認められる N. laryngeus superior Xが，含まれているものと思われると記述している.

したがって著者は, CoRDS ${ }^{3)}$ が記載したR, anterior r. pharyngei は, 著者が記載した迷走神経の咽頭枝 および喉頭枝と同一視されるものと判断する。 そし て，その迷走神経の咽頭枝抢よび喉頭枝の中に，舌 咽神経の線維もかなり混在しているものと考える が，その由来を考虑して，この神経枝を，迷走神経 の咽頭枝および喉頭枝として整理することにした (Figs. 6, 9).

な扮 CoRDS $^{3)}$ は， R. anterior r. pharyngei が，さ らに多くの枝に分伎することを記載し，それらの枝 に個々の学名を与えている，著者は，上述の考察か ら，それらの点はすべて割愛することにした。

5. Rr. esophagei superiores (上食道枝)

舌咽神経は，迷走神経の咽頭枝求よび喉頭枝に神 経線維を与えた後，頸静脈の腹側にそって，頸部を 走下して行くが，その途上で，濑次枝分かれをする. その枝の数は，ほとんどの例で 4 本である。それら の個々の神経枝の未梢部は,大概 2 本に分岐して,食 道に分行している(Fig. 9)。この枝の本幹の終末心，

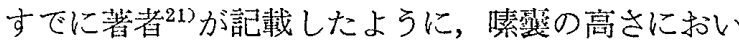
て数本の小忮に分肢し，その大部分は，迷走神経の 1 枝である反回神経の終末枝と吻合する (Fig. 9).

この枝を，BONSDORFF'1) および CORDS ${ }^{3)}$ は R. descendens s. oesophageus sup. とし, STRESEMANN ${ }^{2()}$ は R. pharyngeus として，記載している，著者は， この神経枝の終末分价が，㗪裝までの食道上部にほ

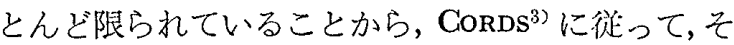
の学名を Rr. esophagei superiores（上食道枝）とし 
て整理した。

$$
\text { 結論 }
$$

鶏における舌下神経，副神経および舌咽神経の走 向ならびに分布について観察し，図示した Figs. 1〜9). 次に, 文献に示された鳥類一般ならびに鶏の 舌下神経, 副神経および舌咽神経に関する学名につ いて，できる限り詳細に検討し，それらを参照して， これらの神経の学名执よび和名を整理し，表示した (Tables 1３). しかし学名については，なお検討の余 地が残されて扔り，将来その点を検討して行きたい。

付 記：なお本論文の完結後在头中の保田教授 より，次の諭文があることを教示さ㣗た。

VON Kurt Ihnen (1928): Beiträge zur Physiologie des Kropfes bei Huhn und Taube. I. Bewegung und Innervation des Kropfes. Pflügers Arch. f. d. ges. Physiol., 218, 767 783.

これによると，著者の Rr. esophagei superiores は，N. oesophageus であり，また著者の迷走神経の 咽頭枝扎よび侯頭枝は，N. laryngo-oesophageusであ る.なお IHNEN の N. recurrens medialis et lateralis については，別の穖会に考察したい上思う。

本研究は, 当教室の共同研究の一部であり,その要 旨は，第 49 回日本獣医学会 (1960 年) に発表した。

指導および本論文の校閲を仰いだ主任教授，保田 幹男博士に感謝の意を表し研究上指等と援助をいた だた当教室の藤岡助教授にも,合わせて感謝する。 な打本諭文の眓版の印刷費については，名古屋畜 産学研究所の援助を仰いた。高配をいただいた同所 理事長增井清博士，ならびに理事近藤恭司博士に愿 く御礼申し上げる。

\section{文献}

1) Bonsdorff, E. J. (1952): Actis societatis scientiarum Fenniae, Helsingfors. CoRds ょり 引用.

2) Chamberlain, F. W. (1943): Atlas of Avian Anatomy, East Lansing, Michigan, Michigan State College Press.

3) Cords, E. (1904): Anat. Hefte, 26, 49 100.

4) 藤岡, 鬼頭, 渡辺, 西田, 保田 (1962): 日本 獣医学雑誌, 24, 附録 416 .

5) 藤凧 (1963): 日本獣医学雑誌, 25, 207 226.

6) Fürbringer, M. (1888): Bijdragen tot de dierkunde, 15 Aufl., Amsterdam, Van Holkema. CORDs ょり引用.
7) Gadow, H. und Selenka, E. (1891): Vögel. I. Anatomischer Theil. Dr. H. G. Bronn's Klassen und Ordnungen des Thier-Reichs, 6 Bd., 4 Abt. CoRds より引ケ.

8) Häcker, V. (1898): Anat. Anz., 14, 521 532.

9) Haller V. G. von Hallerstein (1934): Das zerebrospinales Nervensystem. V. Kranialnerven. Handbuch der vergleichenden Anatomic der Wirbeltiere, von BoLk, L., GöpPERT E., Kallius, E. und Lubosch, W., 2 Bd., s. 632 654, Berlin u. Wien, Urban \& Schwarzenberg.

10) Hamilton, H. L. (1952): Lillie's Development of the Chick: An Introduction to Embryology, 3rd Ed., pp. 332 336, New York, Henry Holt \& Co.

11) Holl, M. (1877): Z. Anat. u. Entwickl., 2. CORDS より引用.

12) Van Der Horst, C. I. (1938): Das zerebrospinales Nervensystem. IV. Spinalnerven. Handbuch der vergleichenden Anatomie der Wirbeltiere, von BoLk, L., GöpPERT, E., Kallius, E. und Lubosch, W., 2 Bd., s. 524 525, Berlin u. Wien, Urban \& Schwarzenberg.

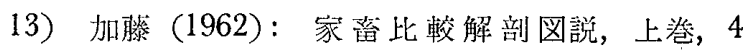
版, 東京, 養賢堂.

14) Kaupp, B.F. (1918): The Anatomy of the Domestic Fowl, pp. 272 275, Philadelphia and London, W. S. Saunders Co.

15) Kesteven, L. (1925): J. Roy. Soc. N.S. Wales, 59, 108 123.

16）鬼頭, 渡辺, 西田, 藤岡, 保田 (1961): 日本 獣医学雑誌, 23, 附録 274 .

17) Lubosch, W. (1899): Arch. mikr. Anat., 54, $514 \sim 602$.

18）西 (1935)：比較解剖学，岩波全畫，59，65 頁, 東京, 岩波書店.

19) Portmann, A. (1950): Système nerveux. Traité de Zoologie, Anatomie-systematique, Biologie, par Grassé, P. P., Tome XV, Oiseaux, p. $197 \sim 200$, Paris, Masson et Cie.

20) Stresemann, E. (1934): Sauropsida: Aves. Handbuch der Zoologie, von KükENTHAL, W., und KrumbaCH, T., 7 Bd., s. 105 106, Berlin 
u. Leipzig, Walter de Gruyter \& Co.

21) 渡辺 (1960): 日本獣医学雑誌, 22, 145 154.

22）渡辺 (1961)：日本獣医学杂倠誌，23，85 99.

23）保田，渡辺，滕閊，西田，鬼頭（1961）：日本
獣医学雑誌，23，附録 475 .

24) YNTema, G. L. and Hammond, W.S. (1945):

J. Exp. Zool., 100, $237 \sim 263$.

\title{
COMPARATIVE AND TOPOGRAPHICAL ANATOMY OF THE FOWL
}

\section{PERIPHERAL GOURSES OF THE HYPOGLOSSAL, ACGESSORY AND GLOSSOPHARYNGEAL NERVES}

\author{
Tohru Watanabe \\ Laboratory of Veterinary Anatomy, Faculty of Agriculture, Nagoya University \\ Chief: Prof. M. YASUDA
}

(Received for Publication January 10, 1964)

The gross anatomy of the distribution of nervus hypoglossus, nervus accessorius, and nervus glossopharyngeus in the fowl was described and illustrated in detail on the basis of 15 cases of complete dissection.

The results obtained are shown in the following tables and plates.

Table 1.

\begin{tabular}{|c|c|c|c|}
\hline $\begin{array}{l}\text { Nomenclature by } \\
\text { CORDS } 1904\end{array}$ & $\begin{array}{l}\text { Nomenclature } \\
\text { in Latin }\end{array}$ & $\begin{array}{l}\text { Nomenclature } \\
\text { in Japanese }\end{array}$ & Organ supplied \\
\hline N. hypoglossus & N. hypoglossus & 舌下神経 & \\
\hline vordere Wurzel & Radix cranialis & 哆側根 & \\
\hline \multirow[t]{3}{*}{ hintere Wurzel } & Radix caudalis & 尾側根 & . \\
\hline & R. anterior & 前 枝 & \\
\hline & R. posterior & 後 枝 & M. rectus capitis ventralis \\
\hline Plexus cervicalis & Plexus hypoglossocervicalis & 舌下頸神経唼 & \\
\hline $\begin{array}{l}\text { Rr. comm. c. n. cervical. } \\
\text { primo }\end{array}$ & $\begin{array}{l}\text { R. communicans cum } n \text {. } \\
\text { cervicali primo } \\
\text { R. comrnunicans cum ganglione } \\
\text { cervicali superiore }\end{array}$ & $\begin{array}{l}\text { 第一頸神経との交通枝 } \\
\text { 上頸神経節との交通枝 }\end{array}$ & \\
\hline R. comm. c. n. vago & R. communicans cum n. vago & $\begin{array}{l}\text { 迷走神経との交道枝 } \\
\text { 下年行钼枝 }\end{array}$ & \\
\hline $\begin{array}{l}\text { R. cervicalis descendens } \\
\text { inferior }\end{array}$ & $\begin{array}{l}\text { R. cervicalis descendens } \\
\text { inferior }\end{array}$ & & M. sternolaryngeus \\
\hline $\begin{array}{l}\text { R. comm. c. n. glosso- } \\
\text { pharyngeo }\end{array}$ & $\begin{array}{l}\text { R. communicans cum n. glosso- } \\
\text { pharyngeo }\end{array}$ & 舌咽神経との交通枝 & \\
\hline R. lingualis & Rr. laryngolinguales & 喉頭舌筋枝 & M. hyomandibularis \\
\hline \multicolumn{4}{|l|}{ R. ad M. tracheohyoideum } \\
\hline Rr. ad M. geniohyoideum & & & M. inierceraioideus \\
\hline $\operatorname{Rr}$ ad M. hyoglossum & & & $\begin{array}{l}\text { M. hyoglossus medialis ef } \\
\text { M. hyoglossus lateralis }\end{array}$ \\
\hline R. laryngeus superior & Rr. laryngei superiores & 上喉頭枝 & \\
\hline
\end{tabular}




\begin{tabular}{|c|c|c|c|}
\hline $\begin{array}{l}\text { Nomenclature by } \\
\text { CORDS } 1904\end{array}$ & $\begin{array}{l}\text { Nomenclature } \\
\text { in Latin }\end{array}$ & $\begin{array}{c}\text { Nomenclature } \\
\text { in Japanese }\end{array}$ & Organ supplied \\
\hline Rr. ad M. bronichotrachealem & & & $\begin{array}{l}\text { M. trachealis lateralis } \\
\text { M. sternolaryngeus }\end{array}$ \\
\hline Rr. ad M. sternotrachealem & R. syringeus & 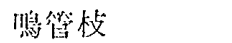 & M. sternotrachealis \\
\hline
\end{tabular}

Table 2.

\begin{tabular}{|c|c|c|c|}
\hline \multirow[t]{3}{*}{ N. accessorius } & N. accessorius & 副神経 & \\
\hline & Radices craniales & 䂑䯙根 & \\
\hline & Radices spinales & 脊骷根 & \\
\hline R. internus & R. internus ? & 内 枝? & \\
\hline R. externus & R. externus & 外 枝 & M. trapezius \\
\hline
\end{tabular}

Table 3.

N. glossopharyngeus

Ganglion jugulare

Ganglion petrosum

R. sphenopalatinus

R. comm. c. r. post. n. facialis

R. comm. c. n. vago

$R$. lingualis

Rr. pharyngei

$R$. ad M. geniohyoideum

R. ad gl. sublingualem

Rr. laryngei externi

R. lingualis sens. strict.

$R$. pharyngeus

$R$. ant. r. pharyngei

Rr. ad M. geniohyoideum

$R$. laryngeus int.

R. descendens s. oesophageus sup.
N. glossopharyngeus

Ganglion radicis glossopharyngei

Ganglion petrosum

$R$. sphenopalatinus

$\mathrm{Rr}$. communicantes cum $\mathrm{n}$. faciaii

$R$. lingualis

Rr. ad m. ceratomandibulares

$\mathrm{Rr}$. ad gll. submandibulares posteriores ef anteriores

R. pharyngeus

$R$. communicans cum $n$. glossopharyngeo

$\mathrm{Rr}$. laryngei ef pharyngei n. vagi

Rr. esophagei superiori
舌咽神経

舌咽神経根神経節

錐体神経節

蝶形口蓋枝

A. carotis interna

顔面神経との交通枝

舌 枝

Lingua

㑇下顎筋への枝

前 - 後顎下腺への枝

M. ceratomandibularis

GII. submandibulares posteriores et anteriores

咽頭枝

Esophagus

舌咽神経との交通枝

迷走神経の喉頭枝及び Larynx ef Pharynx 咽頭枝

上食道枝 


\section{EXPLANATION OF PLATES}

\section{PLATES I IV}

Fig. 1. A scheme showing the glossopharyngeal, vagal, and accessory rootlets.

Fig. 2. Deep dissection showing the two hypoglossal rootlets.

Fig. 3. Posterior view of the skull showing the positions of the formina of glossopharyngeal (IXf), vagoaccessory (Xf), and hypoglossal (XIIf) nerves.

Fig. 4. Superficial dissection showing the peripheral course of the accessory nerve.

Fig. 5. Deep dissection showing the terminal ramification of the Rr. laryngolinguales and R. lingualis.

Fig. 6. A scheme showing connection between five cranial nerves in the upper cervical region.

Fig. 7. Superficial dissection showing the peripheral course of the glossopharyngeal nerve in the upper cervical region.

Fig. 8. Superficial dissection showing the peripheral course of the hypoglossal nerve in the mandibular area.

Fig. 9. A schematic dissection showing the terminal ramification of the hypoglossal and glossopharyngeal nerves.

\section{ABBREVIATIONS}

CI : N. cervicalis primus, CII : N. cervicalis secundus, Vmd: R. mandibularis of N. trigeminus, VII : N. facialis, IX: N. glossopharyngeus, IXf: Foramen n. glossopharyngei, IXl: R. lingualis of N. glossopharyngeus, IXp: R. pharyngeus of N. glossopharyngeus, $X: N$. vagus, Xf: Foramen $n$. vagoaccessorii, Xl-p: Rr. laryngei et pharyngei of $\mathrm{N}$. vagus, XI: N. accessorius, XII : N. hypoglossus, XIIa: R. anterior of N. hypoglossus, XIIcdi: R. cervicalis descendens inferior, XIIfd: Foramen n. hypoglossi dorsale, XIIfv: Foramen n. hypoglossi ventrale, XIIll: R. laryngolingualis, XIIls: R. laryngeus superior, XIIs : R. syringeus, XIIp: R. posterior of N. hypoglossus, E: Esophagus, Gcs: Ganglion cervicale superius, Gp: Ganglion petrosum, GrIX: Ganglion radicis glossopharyngei, GrX: Ganglion radicis vagi, Gmdp: GIl. submandibulares posteriores, Ing: Ingluvies, L: Lingua, Mccl: M. cutaneus colli lateralis, Mcg: M. ceratoglossus, Mcmd: M. ceratomandibularis, Mhgl: M. hyoglossus lateralis, Mhgm: M. hyoglossus medialis, Mhmd: M. hyomandibularis, Mic: M. interceratoideus, Mmp: M. masseter profundus, Mms: M. masseter superficialis, Mom: M. occipitomandibularis, Mrcl: M. rectus capitis lateralis, Mrcv: M. rectus capitis ventralis, Msl : M. sternolaryngeus, Mst: M. sternotrachealis, Mt: M. trapezius, Nlr: N. laryngeus recurrens, Rcs: R. communicans cum ganglio cervicali superiori, Rcp: R. communicans cum n. cervicali primo, rIX: Radices n. glossopharyngei, rX: Radices n. vagi, rXI: Radices n. accessorii, rXIc: Radix cranialis, rXIs: Radix spinalis, rXIIa: Radix anterior of N. hypoglossus, rXIIp: Radix posterior of N. hypoglossus. 

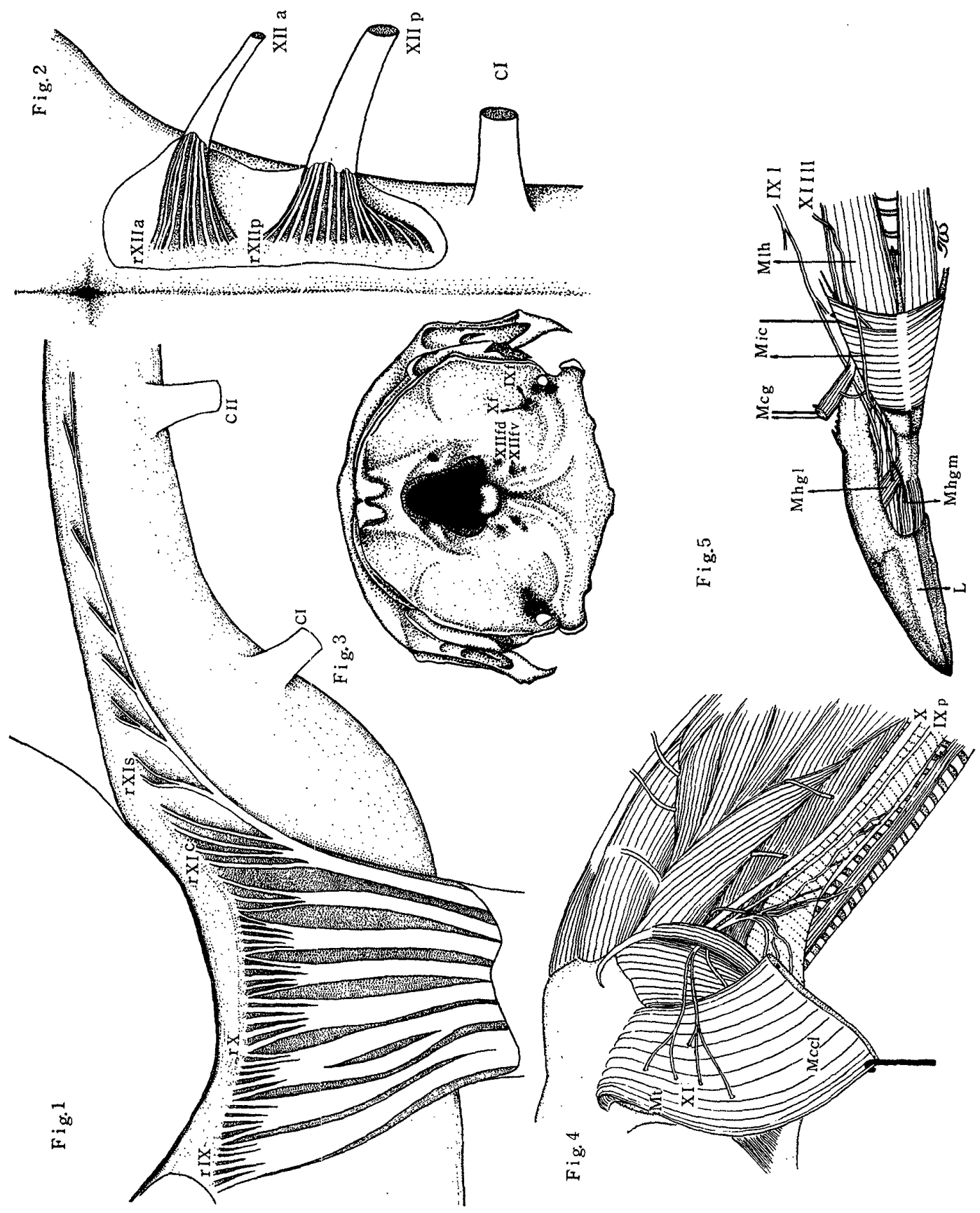


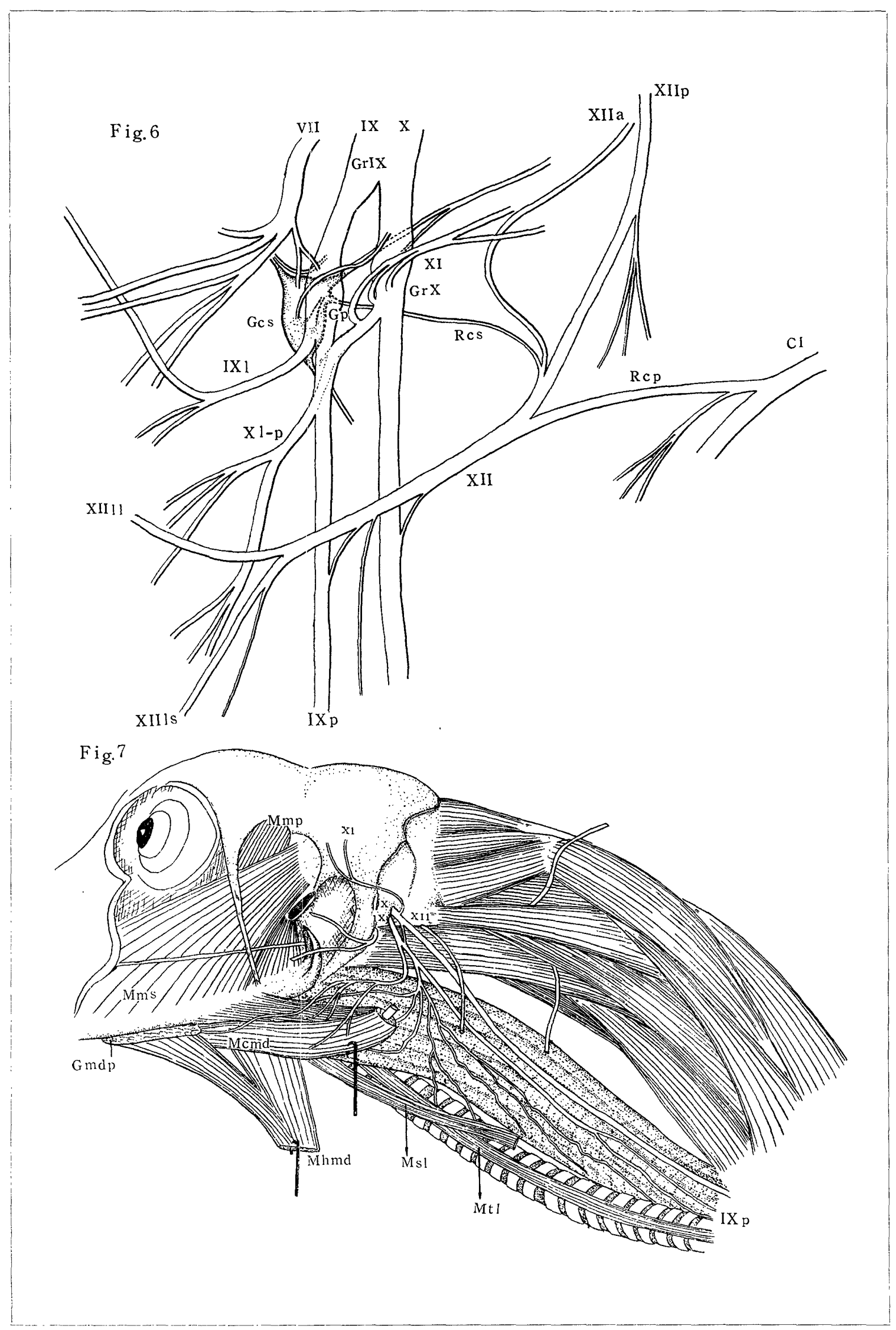




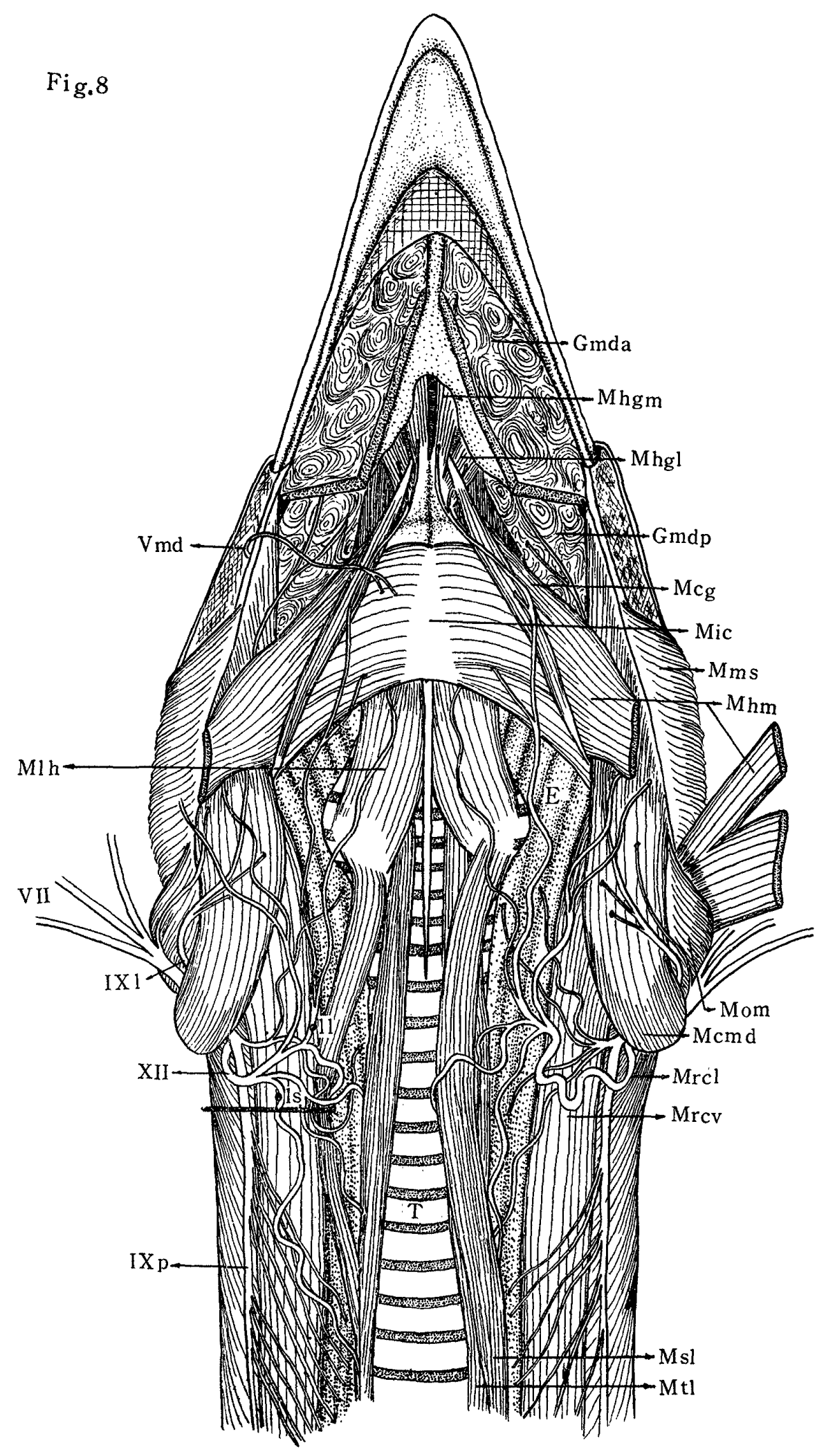




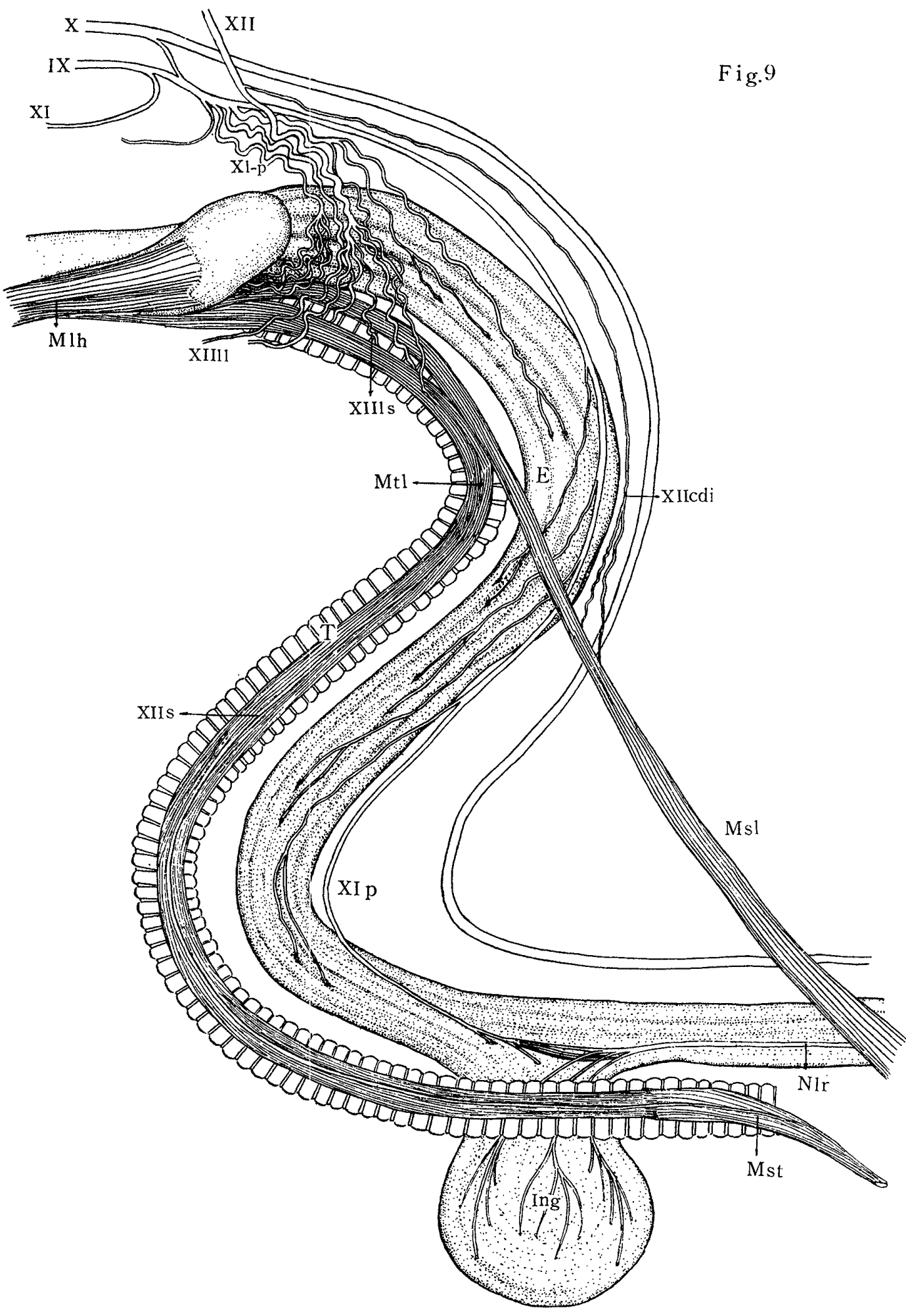

